\title{
DETERMINING PLANTING WINDOW FOR GROWING UPLAND COTTON (GOSSYPIUM HIRSUTUM L.) DURING DRY SEASON IN BANDARBAN, BANGLADESH
}

\author{
A. Hamid ${ }^{1}$, M. G. Neogi', M. S. Marma ${ }^{2}$, J. C. Biswas ${ }^{3}$, A. S. S. Marma ${ }^{1}$, M. A. M. \\ Mollah $^{4}$, M. F. Uddin ${ }^{5}$ and M. M. Islam ${ }^{6}$
}

\begin{abstract}
Farmers in the Chattogram Hill Tracts, Bangladesh have been growing cotton (Gossypium hirsutum L.) in their traditional system of jhum cultivation which is undergoing transformation. Growing rainfed cotton as a monocrop in the uplands is constrained by farmers' socio-economic conditions and erratic rainfall. Shifting growing season to post-monsoon dry monthscould be an option to sustain cotton production in hilly areas. An exploratory experiment was conducted for two seasons to explore the possibility of growing cotton in valley lands in Bandarban during dry season. Growth and yield potentials of dry season cotton were evaluated in relation to prevailing environmental conditions. Night temperature dropped to $9^{\circ} \mathrm{C}$ on several occasions in 2018-2019 season; but it remained higher than $11^{\circ} \mathrm{C}$ throughout the season in 2019-2020. In 2018-2019, day temperatures surged higher past March 15 occasionally exceeding $38^{\circ} \mathrm{C}$. Variability in temperatures was more in 2018-19 while average temperatures were higher in 2019-20 season. Rainfall distribution was almost similar in both the growing seasons receiving total rainfall of $757 \mathrm{~mm}$ and $579 \mathrm{~mm}$ in two seasons, respectively. Higher seed cotton yield (2,047 kg per ha) was recorded for 15 November planted crop compared with 1 December planted crop (1,186 kg per ha). December 1 planted crop was affected more by low temperatures at seedling stage resulting in poor growth and fewer bolls per plant. Late planted crop was more vulnerable to rain damage at boll opening stage. Crops of both the seasons encountered high temperatures $\left(>32^{\circ} \mathrm{C}\right)$ during boll development. Changing climate, shorter winter season and rising temperatures may allow cotton production in valley lands shifting growing season from rainy season to post-monsoon dry months. However, the window of dry season cotton growing in Bandarban, Bangladesh seems narrow. Rainfall pattern restricts planting seeds prior to mid-November. Again, high temperatures stress in March and April synchronizing boll development, and rainfall toward late April and May during boll opening may cause yield loss. Development and adoption of short duration, low temperature tolerant upland cotton varieties might be of advantage for adapting to climate change vulnerabilities.
\end{abstract}

Keywords: Shifting cotton, growing season, valley land, temperature stresses, rain damage, yield.

\footnotetext{
${ }^{1}$ Agrarian Research Foundation, 5/10B, Block A, Lalmatia, Dhaka 1207, Bangladesh, ${ }^{2}$ Hill Cotton Research Station, Cotton Development Board, Balaghata, Bandarban 4600, Bangladesh, ${ }^{3}$ Krishi Gobeshona Foundation, Bangladesh Agricultural Research Council Complex, New Airport Road, Farmgate, Dhaka 1215, Bangladesh, ${ }^{4}$ Kazi Azimuddin College, Joydebpur, Gazipur 1700, Bangladesh, ${ }^{5}$ Cotton Development Board, Khamarbari Rear Building, Khamarbari Road, Dhaka 1215, Bangladesh, ${ }^{6}$ Soil Conservation and Watershed Management Center, Soil Resource Development Institute, Meghla, Bandarban 4600, Bangladesh. *Correspondence: hamid50.arf@gmail.com
} 


\section{Introduction}

Cotton (Gossypium hirsutum L.) is an important fiber crop grown widely both in tropical and sub-tropical countries. It is a major source of natural textile fiber, oil and protein meal, making it one of the most important cash crops in many countries. Bangladesh has had a long tradition of growing cotton for making the world-famous fine cloth muslin which is lost in antiquity. Indigenous varieties or landraces of a short staple, coarse type of cotton, $G$. arboreum L. is grown in the southeastern Chattogram Hill Tracts (CHT) for centuries. The indigenous cotton species isbelieved to have domesticatedin the Indus Valley of the Indian sub-continent and was largely grown in tropical and subtropical regions of South Asia until $19^{\text {th }}$ century (Moulherat et al., 2002; Choudhry and Guitchounts, 2003). Hill cotton is an important cash crop for the farmers of ethnic communities in the CHT. Apart from producing handloom products, the short staple hill cotton produced by the hill farmers are used in religious functions and offering deity to the Buddhist temples. Cotton played a significant role in establishing political and business links between the peoples of the CHT and Bengal since Mughal period (Lewin, 2010).

An indigenous variety Comilla cotton $(G$. arboreum L.) used to be grown in the hills and mountains of south-eastern districts of Bengal as a component crop of jhum or swidden cultivation system. Jhum is a traditional system of growing crops in the sloping uplands where farmers after clearing forest land plant seeds of several crops together. For land clearing, farmers slash bushes and trees, leave the debris to dry under the sun and set on fire to clean the land before the onset of rainy season. On clearing the land after slashing and burning, farmers dibble seeds without tillage. In view of the system of land clearing, jhum is also known as slash-and-burn system of farming. Jhum or slash-and-burn system is believed to be the most ancient system of crop production in the mountainous terrain in south and southeast Asia (Misbahuzzaman, 2016). Jhum is practiced mainly by subsistent farmers (Spedding, 1988) targeting mostly household food security (Nahar et al., 2020) with rice as the major crop in jhum system. Along with rice, cotton is grown as a cash crop. Jhum crops in the hills and mountains are grown rainfed usually without applying fertilizers. As economy develops, communication networks improve and market increasingly impacts on farm economy, jhum system of crop growing is undergoing transformation throughout south and southeast Asia (Padoch et al., 2007; Kingwell-Banhamandand Fuller, 2012; Castella et al., 2015; Heinimann et al., 2017) making the traditional jhum system increasingly unsustainable (Datta, 2014; Nath et al., 2016).

In the medium highlands of floodplains, cotton growing season starts in the month of July and ends in January of the following year. In the hills, however, jhum crops are usually planted in April-May depending on the onset of rain. The CHT, characterized by a unimodal rainfall distribution pattern, receives a rainfall of over 3,000 $\mathrm{mm}$ annually of which over $75 \%$ is in the rainy season, July through September. Incidence of rainfall is predicted to be more intense during the monsoon and lesser in dry season in future due to climate change (Shahid, 2010) with greater degree of uncertainty and climate extremes (Khan et al., 2020). Uncertainty and uneven distribution 
of rainfall often causes low yields and crop loss. Early planted cotton in jhum starts boll opening in September synchronizing with late showers causing boll weathering (Hake et al., 1992) or rain damage of the first flash of bolls. Rain damage of cotton often accounts for a substantial yield loss. Conversely, early cessation of monsoon rain results in terminal drought affecting cotton growth at reproductive and boll development stages. Gao et al. (2020) reported deterioration of fiber quality due to adverse effect of drought stress on cotton plants. Earlier, Wang et al. (2016) reported that drought plants produced fewer and smaller bolls on higher fruiting branch than did the well-watered plants. Boll weight, seed index, and fiber length and strength declined linearly with decreasing mean midday leaf water potential during fruit maturation period.

Jhum being unsustainable (Nath et al., 2016; Nahar et al., 2020) in general, and the adverse effects of erratic rains and drought on jhum cotton in particular, jhum farmers tend to replace cotton with food crops like maize and banana (Anon, 2002; Jafar Ullah et al., 2020). Against the backdrop of climate change and increasing vulnerability of jhum cotton to climate extremes (e.g., drought and excessive rainfall), shifting of growing season from rainy to dry period might be an option. Shifts in plant phenology due to climate change (Wolkovich et al., 2017) may allow fitting cotton in dry season despite mild winter at the early stage of crop growth. Temperature has regulatory role of plant growth and limiting the length of growing season (Luo et al., 2011). Reports on the adverse effects of climate change on crops abound. However, cotton seems to be an exception. Gérardeaux et al. (2013) reported a positive effect of climate change from 2005 to 2050 in North Cameroon on cotton yields with an increase of $1.3 \mathrm{~kg} \mathrm{ha}^{-1}$ year $^{-1}$ in yield. With the winter season shortened and night temperatures increased (Anon, 2018) the changing climate might open up a new opportunity of growing cotton in Bandarban during post-monsoon dry season. However, shifting cotton growing season may not help jhum farmers growing it in the uplands of the hills and mountainous terrain. But it can be grown in the valley land during dry season where spring water for irrigation is available.

Valleys constitute less than $6 \%$ of the total land surface in three districts of the CHT; with much lesser share in Bandarban. High population pressure, increased food demand and growing market put pressure on using valleys. Valley lands are intensively cultivated with myriads of crops planted. Farmers in the valleys along the river Sangu are increasingly getting involved in growing tobacco during winter months. Assured market and easily available production credit allure farmers adopting tobacco cultivation. Expansive cultivation of tobacco is causing health hazards and environmental degradation. Being a signatory of WHO tobacco regulatory framework Bangladesh discourages tobacco production; but farmers are unlikely to give up tobacco cultivation unless a viable and profitable alternative crop is found.

Given the uncertainty in sustaining of cotton growing with jhum in the $\mathrm{CHT}$ during rainy season due to climatic vulnerability and socioeconomic constraints, planting cotton in the dry season might be advantageous, but cold temperatures in the early growth stages may potentially determine dry season planting. 
Temperature is an environmental condition that has pronounced influence on the growth and development of crops. Cotton is highly sensitive to both biotic and abiotic stresses (Luo, 2011; Zahid et al., 2016). Climatic extremes affect every phenological events of cotton to varying degrees (Singh et al., 2007). Low temperatures are reported to have delayed emergence and reduced cotton seedling vigor resulting in poor early growth (Oosterhuis and Jernstedt, 1999). Patterson and Flint (1979) reported that even a short exposure to low temperature of $17 / 13^{\circ} \mathrm{C}$ day/night temperatures significantly reduced dry weight, leaf area and height in cotton. However, cotton varieties/species differ significantly in terms of their tolerance to cold temperatures (Anjum and Khatoon, 2003; Bolek, 2010). Likewise, reports on the adverse effects of high temperatures on cotton growth, development and yield abound (e.g., Oosterhuis and Snider, 2011; Singh et al., 2007). While the farmers consider cotton growing feasible in the southern coastal districts and in the CHT in the dry season, dry season cotton is gaining ground in the coastal districts of Indian state of West Bengal. Transplanting of seedlings in January in intercropping system in Sundarban coastal area of West Bengal (India) obtained seed cotton yields between 1,306 and 1,792 $\mathrm{kg}$ per ha (Maitra et al. 2001). Similar works on growing upland cotton during dry season in Bangladesh has not been reported.

In this paper, the feasibility of growing upland cotton in dry season in the valleys of Bandarban district has been reported by conducting a two-season study and analyzing weather data.

\section{Materials and Methods}

The study was conducted in valley land along the river Sangu in Bandarban, Bangladesh. An exploratory type of single variate experiment was conducted in successive dry seasons- November 2018- May 2019, and December 2019 - May 2020 under irrigated condition. In the first year, an on-farm experiment was set up on a plot in a village Thwingyapara $\left(22^{\circ} 13^{\prime} 03^{\prime \prime} \mathrm{N}\right.$ latitude and $92^{\circ} 12^{\prime} 56^{\prime \prime}$ E longitude) located at the foothill at an altitude of $130 \mathrm{~m}$ above mean sea level. In the following dry season, the experiment was established at the Experimental Farm of Agrarian Research Foundation (ARF), Reicha (22 $\left.10^{\prime} 10^{\prime \prime} \mathrm{N}, 92^{\circ} 10^{\prime} 59^{\prime \prime} \mathrm{E}\right)$.

Hill soils of Bandarban upazila are mostly loamy to sandy loam. In the valley lands of both the experimental locations, however, the soils are silty-clay to clay in nature with fairly a high water holding capacity (SRDI, 2010). A large plot $(50 \mathrm{~m} \times 30 \mathrm{~m})$ was established in the first year. In 2019-20 season, the plot size was reduced to $30 \mathrm{~m} \times 20 \mathrm{~m}$. In each season the plot was split into three sub-plots, each subplot forming a replication. Cotton seeds (cv. $\mathrm{CB} 12$ ) were planted in rows, $0.70 \mathrm{~m}$ apart, on 15 November 2018 and on 01 December 2019. Fertilizer dose used was100-60-80 $\mathrm{kg} \mathrm{ha}^{-1}$ of $\mathrm{N}-\mathrm{P}_{2} \mathrm{O}_{5}-\mathrm{K}_{2} \mathrm{O}$ as urea, triple superphosphate and muriate of potash, respectivelyin both the years. One third of $\mathrm{N}$ and full dose of $\mathrm{P}$ and $\mathrm{K}$ fertilizers were applied at planting, and the remaining $\mathrm{N}$ fertilizer in two equal installments at first square formation and at early boll development stages.

Meteorological data for the growing seasons were obtained from the Soil Conservation and Watershed Management Center, some $10 \mathrm{~km}$ 
south of Thwingyapara and $1 \mathrm{~km}$ north of ARF, Reicha. Key phenological events- emergence, first squire formation, first flowering and first boll opening were determined and related with air temperatures. At maturity seed cotton was harvested manually in two pickings in 201819 season. In the second year, cotton suffered from rain damage and thus a single picking was possible. From each unit plot, a sample area of $5 \mathrm{~m}^{2}$ was harvested for recording seed cotton yield.

Apart from recording yield, Yield attributes were estimated by selecting and harvesting 15 plants at random from each plot. Plant height, number of nodes and branches on main stem, nodal position of the first sympodial branch, number of bolls in each plant and the number of open bolls harvested at each picking were recorded. Weather data pertinent to cotton growing have been presented graphically. Single variate data on yield and yield attributes were statistically analyzed (Tukey, 1977) using means and standard deviation.

\section{Results and Discussion}

\section{Growing season characterization}

Climate in Bandarban is characterized by humid sub-tropical with distinct wet and dry seasons. Usually the wet season starts in the month of July that continues up to September. After the termination of rainy season, however, post-monsoon moist period during October-November prevails. Traditionally, hill cotton (G. arboreum L.) is planted along with other crops in shifting cultivation in the hills at the onset of rainy season, April-May. Upland cotton has been introduced both in the valleys and in the hills in recent years. In the valleys residual soil moisture can usually support crop growth during this period. From December onward a prolonged dry period prevails when evaporative demand supersedes natural precipitation. Climatic condition of Bandarban is well documented (Shahid, 2010; http://live3.bmd.gov.bd/nwp-products/ meteogram/1/bandarban_district_met/). Earlier, Hamid et al. (2019) characterized maize growing season in Bandarban during dry season. Similar work on the shifting of cotton growing season from rainy season to dry season in the region has not been reported.

\section{Prevailing weather during growing seasons}

Temperatures varied a little between the two growing seasons; intra-seasonal variation in temperatures was, however, substantial (Fig. 1). The difference between the highest and the lowest temperatures was the minimum at the beginning of the growing season. But as the season advanced, air temperatures started dropping; the diurnal variation in temperatures began widening. In both the years, diurnal variation in temperatures was the highest during mid-January through mid-February.

In 2018-19 season, night temperatures dropped to $9^{\circ} \mathrm{C}$ on several occasions; but in the subsequent year night temperatures remained higher than $11^{\circ} \mathrm{C}$ throughout the season. In contrast, day temperatures surged higher past March 15 in 2018-19 season, occasionally exceeding $38^{\circ} \mathrm{C}$ although the average temperatures remained relatively higher in 2019-20 season. Optimal temperature for the growth and development of cotton is $25^{\circ} \mathrm{C}$ with lower and upper threshold temperatures ranging between $12^{\circ} \mathrm{C}$ and $32^{\circ} \mathrm{C}$ (Reddy et al., 1999; Bange and Milroy, 2004). However, the range of temperatures required for the 
growth and development of cotton plants varies depending on phenological events. For instance, optimal temperature for germination and seedling development ranges between 28 and $30^{\circ} \mathrm{C}$ while base temperature is about $12^{\circ} \mathrm{C}$ for seed germination and $15.5^{\circ} \mathrm{C}$ for seedling growth (Azhar et al., 2020). Conversely, high temperature stress during reproductive and post-reproductive phases hastens maturity shortening the length of growing season (Wheeler et al., 2000) and reducing yields (Pettigrew, 2008; Reddy et al., 2017) of annual crops. Schlenkera and Roberts (2009) determined the critical threshold temperature for cotton as $32^{\circ} \mathrm{C}$, raising temperature further causes yield decline. Earlier, Reddy et al. (1992) suggested $30 / 22^{\circ} \mathrm{C}$ as optimal temperature optimum for stem elongation, leaf area expansion, and biomass accumulation. Temperature regime prevailing in 2018-19 season was thus sub-optimal during early growth stages while it was supra-optimal past February in both the seasons.

Trend of monthly rainfall during the growing seasons are presented in Figure 2. Rainfalls during October through May were $757 \mathrm{~mm}$ and $579 \mathrm{~mm}$, respectively in 2018-19 and 2019-20 seasons. Rainfall pattern remained similar in both the growing seasons. There was scanty rainfall in October followed by a long dry spell until April. In 2019-20, however, the amount of rainfall in May far exceeded the amount received in the earlier season. From winter rainfall pattern it becomes apparent that irrigation is necessary for growing crops during dry season. Frequency of incidence and amount of rainfall could be an added advantage in reducing irrigation requirements provided the incidence is in vegetative or reproductive stage. Rainfall beyond April synchronizing with boll opening could result in rain damage of cotton.

\section{Phenological stages of cotton}

Except in seedling emergence, striking differences in attaining phenological stages of cotton growth was observed due to variable planting dates (Table 1). When planted on 15 November cotton seedlings required 50 days to attain first squaring while December 1 planted seedlings required 84 days (46\% higher). To attain first flowering December 1 planting in 2019-20 season required 108 days $(50 \%$ more days) compared with November 15 planting in 2018-19 season. However, the seasonal difference in number of days required for boll opening substantially narrowed down. Seasonal variation in days required for attaining cotton phenological stages may be explained from the variation in

Table 1. Seasonal variation in attaining phenological stages of cotton

\begin{tabular}{|c|c|c|c|c|c|c|c|c|c|}
\hline \multirow{2}{*}{$\begin{array}{l}\text { Growing } \\
\text { season }\end{array}$} & \multirow{2}{*}{$\begin{array}{c}\text { Planting } \\
\text { date }\end{array}$} & \multicolumn{2}{|c|}{ Seedling emergence } & \multicolumn{2}{|c|}{ First square formation } & \multicolumn{2}{|c|}{ First flowering } & \multicolumn{2}{|c|}{ First boll opening } \\
\hline & & Date & $\begin{array}{l}\text { Days } \\
\text { required }\end{array}$ & Date & $\begin{array}{c}\text { Days } \\
\text { required }\end{array}$ & Date & $\begin{array}{c}\text { Days } \\
\text { required }\end{array}$ & Date & $\begin{array}{c}\text { Days } \\
\text { required }\end{array}$ \\
\hline $2018-19$ & $\begin{array}{c}\text { Nov 15, } \\
2018\end{array}$ & $\begin{array}{c}\text { Nov } 25, \\
2018\end{array}$ & 10 & $\begin{array}{l}\text { Jan } 5 \text {, } \\
2019\end{array}$ & 50 & $\begin{array}{c}\text { Jan 27, } \\
2019\end{array}$ & 72 & $\begin{array}{c}\text { Apr 13, } \\
2019\end{array}$ & 149 \\
\hline $2019-20$ & $\begin{array}{c}\text { December } \\
1,2019\end{array}$ & $\begin{array}{c}\text { Dec 10, } \\
2019\end{array}$ & 10 & $\begin{array}{c}\text { Feb 23, } \\
2020\end{array}$ & 84 & $\begin{array}{c}\text { March } \\
19,2020\end{array}$ & 108 & $\begin{array}{c}\text { May 3, } \\
2020\end{array}$ & 154 \\
\hline
\end{tabular}


day temperatures of two growing seasons (Fig. 1). Low temperatures prevailing in vegetative stages and early reproductive stage delayed growth of December planted cotton plants in 2019-20 growing season (Amin, 1969; Mauney, 1986) whilerising temperatures in boll development phase might have enhanced boll opening (Reddy et al., 1991; Zafar et al., 2018).

Seasonal variation in plant growth characters

Data on the seasonal variation in growth characteristics of cotton plants are given in Table 2. There was a great deal of differences in plant height between two growing seasons. Plants were generally taller in 2018-19 than in succeeding season. In 2018-19, plant height ranged between $61.3 \mathrm{~cm}$ and 116.62 $\mathrm{cm}$ giving an average of $84.4 \mathrm{~cm}$. However, a high value of SD $( \pm 22.06)$ indicates a high degree of variability in plant height within the population. In the subsequent season, plant height varied between $51 \mathrm{~cm}$ and $75 \mathrm{~cm}$. An average plant of 2019-20 growing season was $26 \%$ shorter than that of an average plant of 2018-19 season. In 2018-19 season, seeds (a) DS 2018-19 —Tmax - Tmin

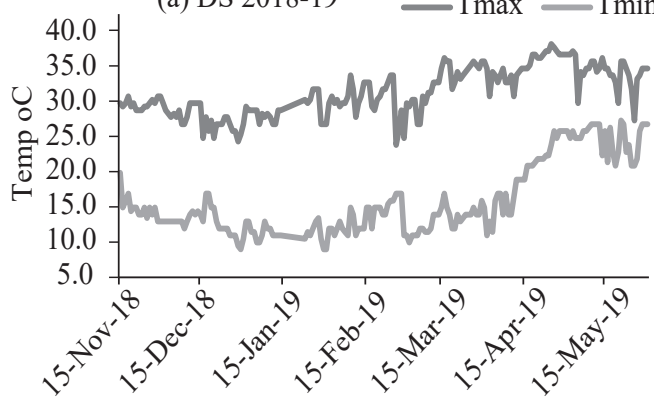

(b) DS 2019-20

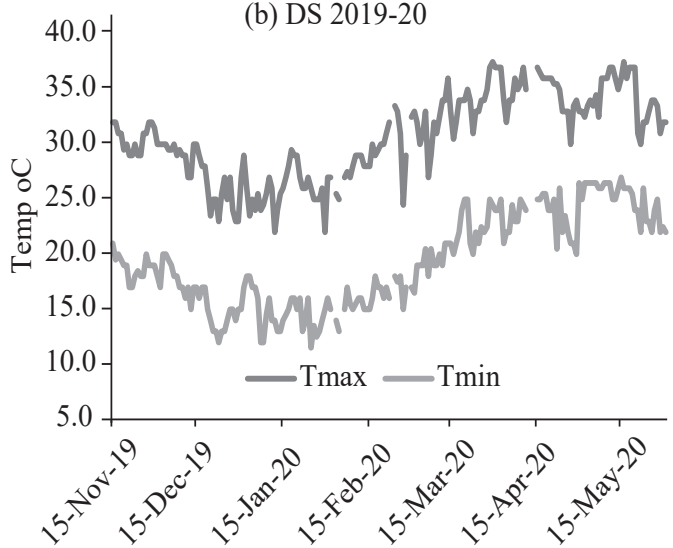

Fig. 1. Seasonal variations in daily maximum $\left(T_{\max }\right)$ and minimum $\left(T_{\min }\right)$ temperatures during in Bandarban, Bangladesh. (a) 2018-19 and (b) 20192020 dry seasons (DS).

Table 2. Seasonal variations in plant characters of cotton grown in 2018-19 and 2019-20 seasons

\begin{tabular}{llcccc}
\hline $\begin{array}{l}\text { Growing } \\
\text { season }\end{array}$ & Plant characters & Min & Max & Average & SD $( \pm)$ \\
\hline $2018-19$ & Plant ht, cm & 61.3 & 111.62 & 84.4 & 22.06 \\
(15 Nov & Nodes on main stem (number) & 23.12 & 33.06 & 25.07 & 3.81 \\
sowing) & Number of branches per plant & 9.8 & 17.5 & 11.3 & 2.04 \\
& Node of first sympodial branch & 6 & 9.38 & 7.3 & 1.06 \\
\hline $2019-20$ & Plant ht, cm & 51 & 75 & 62.8 & 7.02 \\
(01 Dec & Nodes on main stem (number) & 20 & 25 & 22.6 & 1.71 \\
sowing) & Number of branches per plant & 7 & 11 & 8.4 & 1.17 \\
& Node of first sympodial branch & 7 & 10 & 8.8 & 1.03 \\
\hline
\end{tabular}


were planted more than two weeks earlier that helped early germination and seedling establishment prior to experiencing suboptimal temperatures. But in 2019-20 season, seeds were planted on December 1 and such that took longer time to germinate in cooler temperatures. Late planting of seeds in 201920 season synchronizing the onset of winter might have delayed germination and poor early growth (Patterson and Flint, 1979; Hake et al., 1990; Oosterhuis and Jernstedt, 1999; Reddy et al., 2005). The seedlings of both the growing seasons, however, encountered cool temperatures; but seedlings of November 15 planted cotton of 2018-19 season could have been established prior to encountering suboptimal temperatures (Bange and Milroy, 2004). Earlier studies have shown that air temperatures $<16^{\circ} \mathrm{C}$ essentially halt cotton seedling growth (Esparza et al., 2007). In both the seasons, cotton plants suffered from sub-optimal temperatures during early vegetative stages.

The two highly correlated and important criteria (Ray and Richmond, 1966) for determining the length of growth duration- the length of the pre-fruiting period and the nodal position of the first sympodium are influenced by temperature (Reddy et al., 1991). Reddy et al. (2017) demonstrated that regardless of cultivar differences, node numbers and root tips increased linearly with increase in temperature. Length and number of internodes determine the final height of the plant. The number of nodes on main stem varied between 23.2 and 33.06making an average of 25.07 ( \pm 3.81$)$ in $2018-19$ season. The corresponding node numbers in the following season were 20 and 25 respectively with an average of $22.6( \pm 1.71)$. Internode lengths were short in both the seasons $(3.82 \mathrm{~cm}$ and $2.91 \mathrm{~cm}$, respectively) and there was no sign of rank growth. Rather, internode length was too short in the second season making up the plants of short stature. In 2019-20, the number of nodes on the main stem was less variable than in 2018-19.

Each node on the main stem of cotton plant is capable of bearing a branch; but all branches do not bear fruits. Normally the branches developed on the lower 4-7 nodes on the main stem do not bearbolls (fruits) and are called monopodial branches. Fruiting branches are called sympodial. The number of branches per plant varied between 9.8 and 17.5 with an average of $11.3( \pm 2.04)$ branches in201819 season. The number of branches was unusually low compared with the number of nodes developed on the main stem. Fewer branches were produced in the second year which ranged between 7 and 11 with a mean of $8.4( \pm 1.17)$. The first sympodial branch was on node 7.3 in 2018-19 and on node 8.8 in the subsequent season. Development of the first sympodial branch on node 8.4 was rather unusual suggesting a prolonged vegetative growth prior to shifting to reproductive growth. This is also indicative of the plants undergoing stress environment prior to switching to reproductive stage. Vegetative growth has bearing on the initiation and the rate of formation of sympodial branches (Mauney, 1986), and again the rate of vegetative growth prior to onset of flowering is temperature-dependent (Hesketh et al., 1972). Low temperatures for a longer period during seedling and vegetative stages or prior to squiring in both the seasons could have increased the number of nodes and branches (El-Shahawy et al., 1994). But in the present 
study, such a prolonged vegetative phase encountering cool temperatures might have slowed the rate of node and branch formation. Our observations compare favorably with that of Khan (2003) who reported that plants growing in cooler temperatures produce a greater number of nodes to first sympodia than those growing in warmer temperatures.

\section{Seed cotton yield and yield components}

Table 3 summarizes data on seed cotton yield and yield components as influenced by growing season. The number of plants per unit area, harvestable open bolls per plant and individual open boll weight make up the seed cotton yield per unit area. In the present study, we harvested open bolls from $15 \mathrm{~m}^{2}$ predemarcated sample area of each unit plotto record seed cotton yield. Separately sampled 15 plants were harvested from each unit plot cutting at the base and yield attributes determined. As expected, the number of bolls, boll weight and seed cotton yield differed appreciably between the growing seasons. In
2018-19, the number of open bolls per plant ranged between 13.07 and 35.7 with an average of 20.39. A substantial percentage $(25 \%)$ of bolls did not open and could not be harvested. Cotton was harvested for a single picking in 2019-20 growing season and the crop damage due to rainstorm following cyclone Amphan did not allow second picking. The number of bolls per plant decreased appreciably in 2019-20 season recording 9 to 13 harvestable bolls per plant. More than $31 \%$ bolls remained immature and not harvested. Regardless of growing seasons, the number of bolls was appreciably low. The crop encountered low temperature stress following planting that endured throughout seedling and vegetative stages while high temperature stress during reproductive stage enhanced maturity reducing boll development phase. In both the seasons, there was long spell of low temperatures with night temperatures very often lower than $15^{\circ} \mathrm{C}$ (Fig. 1). Cotton plants exposed to temperatures $\leq 20^{\circ} \mathrm{C}$ at any phenological stage have a slowing down effect on the growth

Table 3. Seasonal variation in yield and yield attributes of cotton

\begin{tabular}{llcccc}
\hline Growing season & Yield attributes & Minimum & Maximum & Average & SD $( \pm)$ \\
\hline 2018-19 & No. open bolls per plant & 13.07 & 35.7 & 20.39 & 3.44 \\
(15 Nov sowing) & No. bolls not opened & 2.1 & 8.7 & 6.8 & 2.83 \\
& \% open boll & 58.19 & 80.66 & 74.99 & 4.17 \\
& Open boll wt per plant (g) & 61.08 & 94.41 & 91.55 & 10.03 \\
& Boll weight $\left(\mathrm{g}\right.$ boll $\left.{ }^{-1}\right)$ & 3.22 & 6.03 & 4.63 & 0.71 \\
& Seed cotton yield $\left(\mathrm{kg} \mathrm{ha}^{-1}\right)$ & 961 & 2,743 & 2,047 & 127 \\
\hline 2019-20 & No. open bolls per plant & 9 & 13 & 10.6 & 1.17 \\
(01 Dec sowing) & No. bolls not opened & 4 & 7 & 4.8 & 1.03 \\
& \% open boll & 65 & 69.23 & 68.83 & 53.2 \\
& Open boll wt per plant $(\mathrm{g})$ & 28 & 39 & 31.9 & 3.67 \\
& Boll weight $\left(\mathrm{g}\right.$ boll $\left.{ }^{-1}\right)$ & 2.69 & 3.4 & 3.01 & 0.26 \\
& Seed cotton yield $\left(\mathrm{kg} \mathrm{ha}^{-1}\right)$ & 738 & 2,106 & 1,186 & 114.4 \\
\hline
\end{tabular}



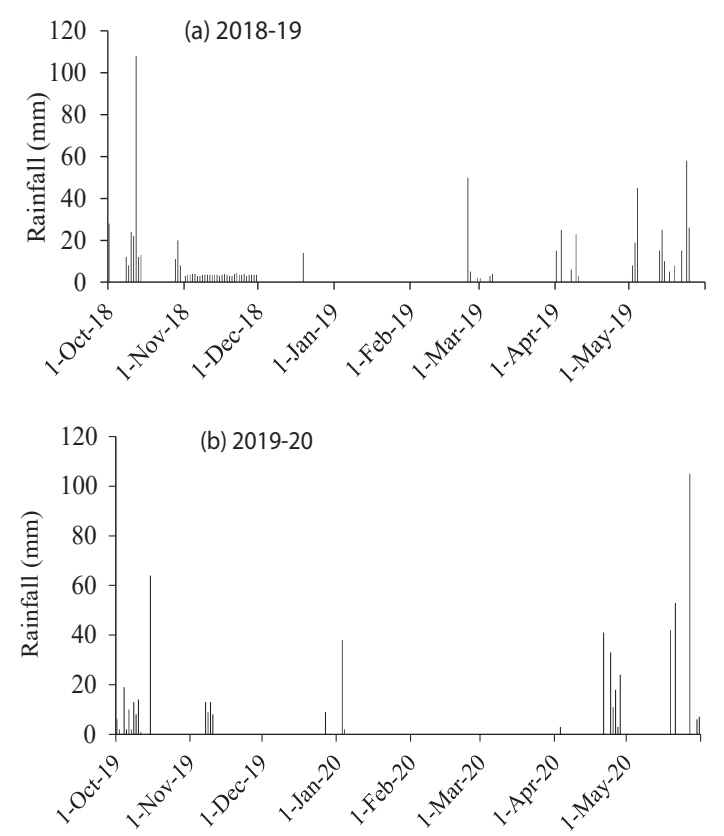

Fig. 2. Rainfall distribution patterns during dry seasons (a) DS 2018-19 and (b) DS 2019-20 in Bandarban, Bangladesh.

(Burke et al., 1988; Reddy et al., 1991. Since cotton seeds were planted 15 November (201819 season) or 1 December (2019-20 season), cotton plants had to undergo low temperature stress with occasional 'cold shock' (Bange and Milroy, 2004) during seedling stage. Again, as day temperatures exceeded $32^{\circ} \mathrm{C}$ past midFebruary (Fig. 2), plants encountered high temperature stress during reproductive and boll development stages.

A high degree of heterogeneity in seed cotton yield was observed (Table 3 ) in both the growing seasons. Seed cotton yield averaged 2,047 $( \pm 127) \mathrm{kg} \mathrm{ha}^{-1}$ in 2018-19, which was reduced to $1,186( \pm 114) \mathrm{kg} \mathrm{ha}^{-1}$ in 201920. The yields were rather low in both the growing seasons compared with average yields obtained the hills when grown in summer season (CDB, 2020). The low yield was associated with lesser number of bolls per plant and low boll weight. Low temperatures at the early growth stages might have reduced boll formation while high temperatures reduced the size and number of bolls retained. Reasons of lower yields become apparent when Figures 1 and 2, and Table 1 are viewed in conjunction. Cotton plants started flowering in late January during 2018-19 growing season, while in the subsequent season, flowering started nearly two months later. December planted crop encountered low temperatures throughout vegetative phase and high temperatures during reproductive and boll development phases. Prolonged supraoptimal temperatures $\left(>35^{\circ} \mathrm{C}\right)$ past vegetative phase might have caused shedding of squares and bolls (Reddy et al., 1992). Costa (2015) indicated that $38 / 30^{\circ} \mathrm{C}$ (day/night) temperature conditions caused a reduced boll size and a substantial decline in non-structural carbohydrate content. Table 1 also shows that in 2018-19 growing season that the duration between first flowering and first boll opening was 77 days which shortened to 46 days for the 2019-20 growing season suggesting that high temperatures hastened boll development and boll opening (Ehlig, 1986; Sawan et al., 1999). Again, rainfall coincided with boll opening in both the growing seasons, but since growth in reproductive and reproductive phases delayed, cotton plants encountered rains almost throughout boll opening phase in 2019-20 season (Fig. 2 and Table 1). Hake et al. (1992) also reported similar yield loss of cotton due to rain damage.

Temperature influences cotton growth and development and thus the onset and termination of cotton growing season depend 
largely on prevailing temperature regime. Bolls per plant and boll weight are the two yield components playing major role in the variation in seed cotton yield. In our study, seed cotton yield varied widely between the seasons. Variation in seed cotton yield was associated with the seasonal variation in both the components. Differences in yield attributes might be attributed to the differences in temperature regimes prevailing during the growing seasons. Apart from the differences in planting dates between the two growing seasons, adverse effects of supraand sub-optimal temperatures, rain damage of open bolls also reduced seed cotton yield in 2019-20 season.

\section{Conclusion}

Hill cotton ( $G$. arboreum L.) used to be planted in the hill slope as a component of jhum crop shas been gradually replaced with upland cotton (Gossypium hirsutum L.) over the past few years. However, the system being labor intensive and low productive its sustainability is being challenged. With changing climate boll opening of upland cotton very often encounters high rainfall making the crop vulnerable to weather damage resulting to low yields. Climate change impact is already visible in terms of rising temperatures and shorter winter season. These changes may allow shifting cotton growing from rainy season to dry season. Warmer temperatures during winter allow growing cotton during post-monsoon dry period. From our results, it becomes apparent that the window of growing cotton during dry season is very narrow. Valley lands in Bandarban are intensively used and making the land available for dry season cropping earlier than November would be difficult. However, even if the seeds are planted in early November, there could be a long growing season of 5-6 months before the onset of rainy season. But low night temperatures during December-January and high temperatures in March are not conducive of getting higher yield. Observations for two growing seasons also indicate the likelihood of rainfall with potential vulnerability of rain damage of open bolls from early May onward. In order to avoid such climate vulnerabilities development and adoption of short-duration varieties of upland cotton might be an effective tool for shifting the cotton growing season from wet season to post-monsoon dry season in Bandarban. Results presented in this paper may contribute to scientific insight of the opportunities presented by the changing climate and also may provide opportunity of harnessing cotton yield potentials shifting the cotton growing season in the CHT.

\section{Acknowledgement}

The work was partially funded by the Ministry of Science and Technology, Government of Bangladesh through Special Allocation Program 2019-20. We are grateful to Chai Thowai Mong Marma of Thwingyapara (Bandarban) village for allowing us running the experiment in his plot during 2018-19 dry season. We are thankful to two anonymous reviewers who helped us improving the paper.

\section{References}

Amin, J. V. 1969. Growth and development of cold-injured cotton plants. Plant Soil. 31(2): 365-373

Anjum, Z. I. and A. Khatoon. 2003. Chilling effect on germination and seedling vigor of some cultivated species of Gossypium. Asian J. Plant Sci. 2(3): 297-299. 
Anonymous. 2002. Mountain Issues and Communities in Chittagong Hill Tracts of Bangladesh. Policy Brief \#3. South Asia Watch on Trade, Economics and Environment (SAWTEE), Kathmandu, Nepal 4 P.

Anonymous. 2018. Climate Change Profile: Bangladesh. Ministry of Foreign Affairs of the Netherlands, The Hague. 28 P. www.government.nl/foreign-policyevaluations. Accessed 10 Oct 2020.

Azhar, M. T., S. H. Wani, T. Jameel, P. Kaur and X. Du. 2020. Heat Tolerance in Cotton: Morphological, Physiological, and Genetic Perspectives. In Wani, SH and Kumar V. (eds.) Heat Stress Tolerance in Plants: Physiological, Molecular and Genetic Perspectives, First Edition. John Wiley \& Sons, New York.

Azhar, M. T., S. H. Wani, M. T. Chaudhary et al. 2020. Heat Tolerance in Cotton: Morphological, Physiological and Genetic Perspectives. Pp. 1-22. In Wani, S. H. and V. Kumar (ed.) Heat Stress Tolerance in Plants: Physiological, Molecular and Genetic Perspectives. (1st ed.) John Wiley and Sons.

Bolek, Y. 2010. Genetic variability among cotton genotypes for cold tolerance. Field Crop. Res. 119: 59-67. doi.org/10.1016/j. fcr.2010.06.015

Burke, J. J., J. R. Mahan and J. L. Hatfield. 1988. Crop-specific thermal kinetic windows in relation to wheat and cotton biomass production. Agron. J. 80(4): 553-556.

Castella, J. C. and J. F. Kibler. 2015. Towards an agroecological transition in Southeast Asia: Cultivating diversity and developing synergies. GRET, Vientiane, Lao PDR 99 P.

Chaudhry, M. R. and A. Guitchounts. 2003. Cotton Facts. Int. Cotton Adv. Committee. Washington D.C 172 P.
Costa, M. S. B. 2015. Temperature in the Cotton (Gossypium hirsutum L.) Canopy and Effects on Cotton Leaf and Boll Growth. An MS thesis submitted to University of Arkansas 103 P.

Cotton Development Board (CDB). 2020. Annual Report 2019, Ministry of Agriculture, Government of Bangladesh 9 P.

Datta, J., N. R. Gangadharappa and A. Debnath. 2014. Sustainability of Jhum cultivation as perceived by the tribal people of Tripura. Int. J. Social Sci. 3(2): 179.

Ehlig, C. F. 1986. Effects of high temperatures and controlled fruiting on cotton yield. Pp. 57-62. In Mauney, J. R. and J. Stewart (ed.). Cotton Physiology. The Cotton Foundation, Memphis, Tennessee, U.S.A.

Ekinci, R., S. Basbag, E. Karademir and C. Karademir. 2017. The effects of high temperature stress on some agronomic characters in cotton. Pak. J. Bot. 49(2): 503-508

El-Shahawy, M. I. and E. A. El-GahelSM, Makram. 1994. Effect of planting dates, hill spacing and nitrogen levels on Giza76 cotton cultivar. J. Agric. Res. Tanta Univ. 20: 631-642.

Esparza, A. M., P. H. Gowda, R. L. Baumhardt and T. Marek. 2007. Heat Unit Availability for Cotton Production in the Ogallala Aquifer Region of the United States. $J$. Cotton Sci. 11:110-117.

Gao, M., S. L. Snider, H. Bai, W. Hu, R. Wang, Y. Meng, Y. Yang, Y. Wang, B. Chen and Z. Zhou. 2020. Drought effects on cotton (Gossypium hirsutum L.) fibre quality and fibre sucrose metabolism during the flowering and boll formation period. $J$. Agron. Crop Sci. 26: 309-321.

Gérardeaux, E., B. Sultan, O. Palaiand and C. Guiziou. 2013. Positive effect of climate change on cotton in 2050 by $\mathrm{CO}_{2}$ enrichment and conservation agriculture in Cameroon. Agron. Sust. Dev. 33: 485-495. 
Hake, K., J. C. Banks, F.Bourland, P. Sasser, P. Tugwell and R. Williford. 1992. Boll Weathering. Cotton Physiol. Tod. 3(10): $1-4$.

Hake, K., W. McCarty, N. Hopper and G. Jividen. 1990. Seed quality and germination. Cotton Physiol. Tod. 3(7): 4.

Hamid, A., M. A. Akbar, M. J. Ullah, M. S. Marma, M. M. Islam, J. C. Biswas and M. G. Neogi. 2020. Spatiotemporal Variations in Temperature Accumulation, Phenological Development and Grain Yield of Maize (Zea mays L.). J. Agric. Sci. 12(1): 46-57.

Hatfield, J. L. and J. H. Prueger. 2015. Temperature extremes: Effect on plant growth and development. Pp. 4-10. Weather and Climate Extremes, Part A. 1

Heinimann, A., O. Mertz, S. Frolking, A. E. Christensen, K. Hurni, Sedano, L.P. Chini, R. Sahajpal, M. Hansen and G. Hurtt. 2017. A global view of shifting cultivation: Recent, current, and future extent. PLOS ONE. 2017. 12(9): e0184479.

Hesketh, J. D., D. N. Baker and W. G. Duncan. 1972. Simulation of growth and yield in cotton. II. Environ. Contr. Morphogen. 12: 436-439.

Islam, A. K. M., S. B. Murshed, M. S. A. Khan and M. A. Hasan. 2014. Impact of Climate Change on Heavy Rainfall in Bangladesh. Bangladesh University of Engineering and Technology, Dhaka 88 P. https:// citeseerx.ist.psu.edu/viewdocad? doi= 10.1.1.727.8506\&rep =rep $1 \&$ type $=$ pdf

Emergence, Growth, and Development. Agron. J. 109: 1379-1387.

Reddy, K. R., D. Brand, C. Wijewardana and W. Gao. 2017. Temperature effects on cotton seedling emergence, growth and development. Agron. J. 109(4): 13791387.
Reddy, K. R., G. H. Davidonis, A. S. Johnson and B. T. Vinyard. 1999. Temperature regime and carbon dioxide enrichment alter cotton boll development and fiber Properties. Agron. J. 91: 851-858.

Reddy, K. R., H. F. Hodges and V. R. Reddy. 1992. Temperature effects on cotton fruit retention. Agron. J. 84: 26-30.

Reddy, K. R., P. V. V. Prasad and V. G. Kakani. 2005. Crop responses to elevated carbon dioxide and interactions with temperature: cotton. J. Crop Improv. 13: 157-191.

Reddy, V. R., K. R. Reddy and D. N. Baker. 1991. Temperature effect on growth and development of cotton during the fruiting period. Agron. J. 83: 211-217.

Sawan, Z. M., L. I. Hanna and W. L. Mccuistion. 1999. Effect of climatic factors during the development periods of flowering and boll formation on the production of Egyptian cotton (Gossypium barbadense L.). Agronomie. 19(6): 435-443.

Schlenker, W. and M. J. Roberts. 2009. Nonlinear temperature effects indicate severe damages to U.S. crop yields under climate change. Proc Natl Acad Sci USA. 106(37): 15594-15598.

Shahid, S. 2010. Recent trends in the climate of Bangladesh. Climat. Res. 42(3): 185-193.

Singh, R. P., P. V. Vara Prasad, K. Sunita, S. N. Giri and K. R. Reddy. 2007. Influence of high temperature and breeding for heat tolerance in cotton: A Review. $A d v$. Agron. 93: 313-385

Soil Resource Development Institute (SRDI). 2010. Manual on Land and Soil Resource Use. Bandarban Sadar (Revised edition). Soil Resource Development Institute, Ministry of Agriculture, Government of Bangladesh, Dhaka. 2010. 212 pp.

Spedding, C. R. W. 1988. Subsistence farming and shifting cultivation. Pp. 114-119. In An Introduction to Agricultural Systems. Elsevier Applied Science Publishers Ltd. 
Tukey, J. W. 1977. Exploratory Data Analysis. Addison Wesley Publishing Company, Reading. $711 \mathrm{P}$.

Ullah, M. J., M. A. Akbar and M. A. Z. Sarker. 2020. Prospects and Cultivation Practices of White Maize - A Secondary Staple Crop for Bangladesh. Sher-e-Bangla Agricultural University, Dhaka. 145 P.

Wang, R., S. Ji, P. Zhang and Y. Meng. 2016. Drought effects on cotton yield and fiber quality on different fruiting branches. Crop Sci. 56(3).

Wheeler, T. R., P. Q. Craufurd, R. H. Ellis, J. R. Porter and P. V. Vara Prasad. 2000. Temperature variability and the yield of annual crops. Agricult. Ecosyst. Environ. 82: 159-167.
Wolkovich, E. M., D. O. Burge, M. A. Walker and K. A. Nicholas. 2017. Phenological diversity provides opportunities for climate change adaptation in wine grapes. J. Ecol. 105: 905-912.

Zafar, S. A., M. A. Noor, M. A. Waqas, X. Wang, T. Shaheen, M. Raza, and Mehboob-UrRahman. 2018. Temperature extremes in cotton production and mitigation strategies. In Past, present and future trends in cotton breeding. InTech.

Zahid, K. R., F. Ali, F. Shah, M. Younas, T. Shah, D. Shahwar, W. Hassan, Z. Ahmad, C. Qi, Y. Lu, A. Iqbal, and W. Wu. 2016. Response and tolerance mechanism of cotton Gossypium hirsutum L. to elevated temperature stress: A Review. Front. Plant Sci. 7: 937. 